\title{
Detection of Unknown Gene Mutations by Multiplex Single-strand Conformation Polymorphism (MSSCP)
}

\section{Fawzy A. Saad, Libero Vitiello, Salvatore Oliviero, Maria L. Mostacciuolo, and Gian A. Danieli}

Department of Biology, University of Padua, Padua, Italy
Detecting unknown mutations is a problem common to most genes, because of the large degree of heterogeneity of DNA variations leading to the expression of a mutant phenotype. The issue is particularly relevant in humans, where it is very important to pinpoint single mutations producing inherited diseases, not only for practical purposes such as prenatal or presymptomatic diagnosis, but also for the study of possible correlations between the kind of mutation and the clinical phenotype.

Although different methods were devised for this purpose, such as chemical cleavage, ${ }^{(1)}$ denaturing gradient gel electrophoresis (DGGE), ${ }^{(2)}$ and temeprature gradient gel electrophoresis (TGGE), ${ }^{(3)}$ single-strand conformation polymorphism $(\mathrm{SSCP})^{(4)}$ is perhaps the most popular method described to date. The rationale of the method is that singlestranded DNA sequences differing by a single-base change may show different electrophoretic mobility in a polyacrylamide gel because of conformational change produced by the substitution. ${ }^{(4)}$

Multiplex PCR amplification was originally devised for detection of exon deletions $^{(5)}$ in the human dystrophin gene. A modification of this method, using polyacrylamide gel electrophoresis, was later introduced, allowing the detection of intraexonic deletions or duplications. ${ }^{(6)}$

A first attempt at developing multiplex SSCP was reported recently. The investigators succeeded in detecting 4 base substitutions by radioactive multiplex PCR amplification, followed by gel electrophoresis of the denatured amplification products. ${ }^{(7)}$ The size of the amplification products in which base substitutions were detected ranged from 238 to $547 \mathrm{bp}$.

A further refinement of this approach is reported here. To obtain sharper resolution, the present method implies the labeling of all forward primers involved in the multiplex PCR amplification, instead of using labeled dNTP.

\section{MATERIALS AND METHODS}

DNA samples were obtained either by phenol/chloroform extraction or by salting-out, from peripheral blood samples, according to standard procedures. The control DNA was from healthy males, whereas the mutated DNAs were from patients affected by Duchenne muscular dystrophy, in whom base substitutions were characterized previously by DNA sequencing. ${ }^{(8)}$

Forward primers (MedProbe) for the amplification of different exons of the dystrophin gene were 5 -end-labeled with $\left[\gamma^{-32} \mathrm{P}\right]$ ATP, by using T4 polynucleotide kinase (Promega).

In a final volume of $10 \mu \mathrm{l}, 10$ pmoles of dephosphorylated forward primers were incubated for $30 \mathrm{~min}$ at $37^{\circ} \mathrm{C}$ in the presence of 5 pmoles of $\left[\gamma^{-32}\right.$ P]ATP [3000 $\mathrm{Ci} / \mathrm{mmole} ; 10 \mu \mathrm{Ci} / \mu \mathrm{l}$ (Amersham)] in appropriate buffer $[0.5 \mathrm{M}$ Tris- $\mathrm{HCl}(\mathrm{pH} 8.0)$, $0.1 \mathrm{M} \mathrm{MgCl}_{2}, 50$ mм DTT, $1 \mathrm{~mm}$ spermidine, $1 \mathrm{~mm}$ EDTA].

After incubation, the kinase was inactivated by heating at $90^{\circ} \mathrm{C}$ for $2 \mathrm{~min}$. The solution was then stored at $-20^{\circ} \mathrm{C}$ before use for as long as 1 month. In a standard multiplex PCR, $200 \mathrm{ng}$ of human genomic DNA was added to $25 \mu \mathrm{l}$ of mixture [1.5 mM MgCl $2,67 \mathrm{~mm}$ Tris- $\mathrm{HCl}(\mathrm{pH}$ 8.8), $\quad 16.6 \mathrm{~mm}$ ammonium sulfate, $0.001 \%$ Tween $20,200 \mu \mathrm{M}$ of each dNTP, 4.25 pmoles of each reverse primer, 0.5 pmoles of each labeled forward primer, 2.5 pmoles of each nonlabeled forward primer, and 2 units of recombinant thermostable DNA polymerase RTB (Bioline, Italy)]. The cycles $\left(3 \mathrm{~min}\right.$ at $94^{\circ} \mathrm{C}$, followed by 25 steps of $30 \mathrm{sec}$ at $94^{\circ} \mathrm{C}$, and $2 \mathrm{~min}$ at $65^{\circ} \mathrm{C}$ ) were performed by a PTC100 MJ Research, Inc., Thermocycler. Vertical slab electrophoreses $(40 \times 20$ $\mathrm{cm}, 0.04 \mathrm{~cm}$ thick) were run on $8 \%$ polyacrylamide gel (29:1 acrylamide/bisacrylamide) added with $10 \%$ glycerol, at room temperature, using $1 \times$ TBE buffer (45 mM Tris-borate at $\mathrm{pH} 8.3 ; 4 \mathrm{~mm}$ EDTA) at 25 watts for $6 \mathrm{hr}$. A metal plate was attached to the front plate of the vertical gel apparatus to ensure thermal homogeneity.

Just before loading the samples, $4 \mu \mathrm{l}$ of the amplification product was denatured by adding $4 \mu \mathrm{l}$ of denaturing loading buffer $(95 \%$ formamide, $20 \mathrm{~mm}$ EDTA, $0.05 \%$ bromphenol blue, $0.05 \%$ xylene cyanol). The solution was heated $\left(94^{\circ} \mathrm{C}\right)$ for $2 \mathrm{~min}$ and then chilled immediately on ice.

After electrophoresis, the gels remained for $1 \mathrm{hr}$ in a Bio-Rad gel dryer (model 583). Once desiccated, they were autoradiographed (Hyperfilm-MP, Amersham) by a 16-hr exposure at room temperature. 


\section{RESULTS AND DISCUSSION}

An example of multiplex SSCP is reported in Figure 1: One set of 10 different amplification products was separated by polyacrylamide gel electrophoresis under the conditions described above. In this case, the size of the amplification products ranged from 100 to $547 \mathrm{bp}$. Shifts in the electrophoretic mobility of

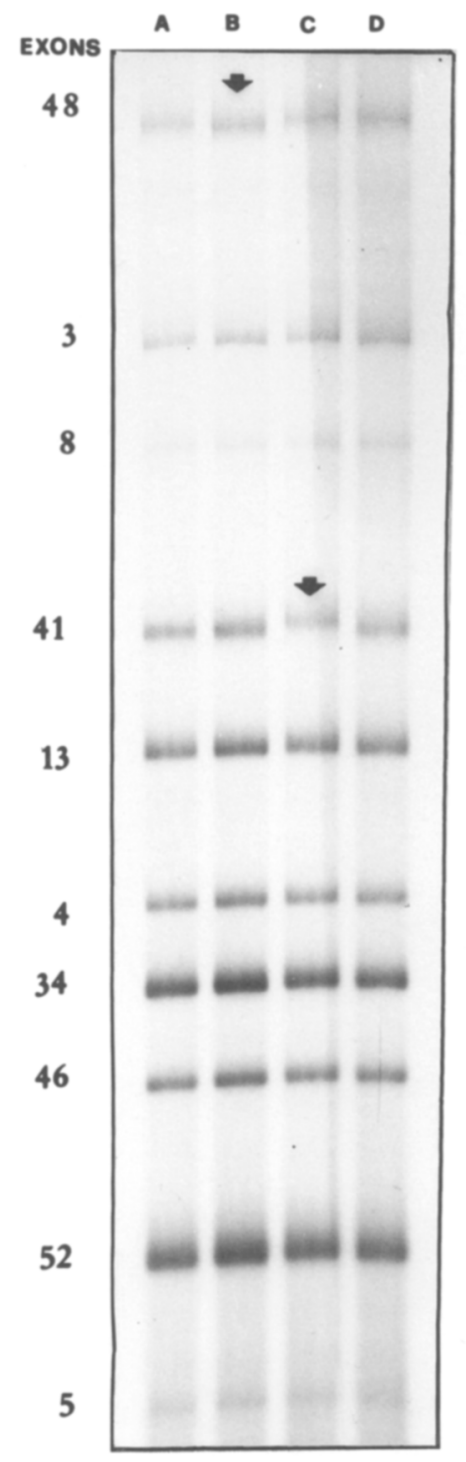

FIGURE 1. Autoradiographs obtained from multiplex SSCP. Ten different exons of the dystrophin gene were amplified in a multiplex PCR reaction in which forward primers were radioactively labeled. The mobility shifts are indicated (arrows). The number of different exons is specified at left. (Lanes $A, D$ ) DNA from a male control subject; (lane $B$ ) patient $620(\mathrm{~A} \rightarrow \mathrm{T}$ substitution in the amplification product of exon 48); and (lane $C$ ) DNA from patient $535(\mathrm{C} \rightarrow \mathrm{T}$ substitution in exon 41$)$.
DNA fragments are clearly visible. In this case, the base substitutions were detected in sequences of 275 and $506 \mathrm{bp}$. Therefore, this method would enable us to detect base substitutions in amplification products as large as $500 \mathrm{bp}$. The possibility of detecting base changes in sequences cannot be excluded, because a mutation was detected by SSCP in an amplification product that was 547 bp long. ${ }^{(7)}$

The sensitivity of the method might possibly be improved by controlling the temperature of the gel matrix. In the experimental conditions described in this paper, the temperature of the gel matrix was $\sim 30^{\circ} \mathrm{C}$, which proved to be optimal, empirically. A poorer resolution was obtained with lower temperatures $\left(\sim 20^{\circ} \mathrm{C}\right)$.

According to present knowledge, the probability of detecting a point mutation as a single strand electrophoretic mobility shift was estimated to be $99 \%$ for fragments up to $300 \mathrm{bp}$ and $\sim 90 \%$ for fragments from 300 to $450 \mathrm{bp} .{ }^{(9)}$ Methods alternative to SSCP for detecting point mutations are presently less sensitive or technically more complicated. For instance, chemical cleavage, which is the most powerful method described so far, involves complicated protocols and the use of hazardous chemicals.

The present method is very simple and the single-stranded labeling of the amplification products strongly ameliorates the resolution of electrophoretic bands. The number of single amplification products included in the multiplex amplification might even be increased. By choosing appropriate sets of multiplex PCR, large segments of a given gene may be easily screened to detect unknown mutations. As far as the dystrophin gene is concerned, the present method enables us to perform simultaneously the screening for exonic deletions, for intraexonic deletions, additions, or duplications, and for a number of base substitutions.

Despite the size of the coding sequence $(14 \mathrm{~kb})$ and the large number of exons to be screened (79), only eight sets of multiplex PCR might enable us to detect the large majority of mutations in any patient affected with Duchenne or Becker muscular dystrophy.

\section{ACKNOWLEDGMENTS}

F.A.S. is the recipient of a Ph.D. scholar- ship by the Italian Ministry of Foreign Affairs. The financial support of TELETHON-ITALY (grant to S.O.) is gratefully acknowledged.

\section{NOTE ADDED IN PROOF}

The possible reassociation and the formation of double-stranded molecules can be prevented by increasing the concentration of formamide in the loading buffer and by working at very low concentrations of DNA. The visualization of SSCP is enhanced by strongly reducing the concentration of the unlabeled molecules of the forward primers.

\section{REFERENCES}

1. Cotton, R.G., N.R. Rodrigues, and R.D. Campbell. 1988. Reactivity of cytosine and thymine in single base pair mismatches with hydroxylamine and osmium tetroxide and its application to the study of mutations. Proc. Natl. Acad. Sci. 85: 4397-4401.

2. Fisher, S.G. and L.S. Lerman. 1983. DNA fragments differing by single base pair substitutions are separated in denaturing gradient gels: Correspondence with melting theory. Proc. Natl. Acad. Sci. 80: 15791583.

3. Wartell, R.M., S.H. Hosseini, and C.P. Moran. 1990. Detecting base pair substitutions in DNA fragments by temperature gradient gel electrophoresis. Nucleic Acids Res. 18: 2699-2705.

4. Orita, M., Y. Suzuki, T. Sekiya, and K. Hayashi. 1989. Rapid and sensitive detection of point mutations and DNA polymorphisms using polymerase chain reaction. Genomics 5: 874-879.

5. Chamberlain, J.S., R.A. Gibbs, J.E. Ranier, P.N. Nguyen, and C.T. Kaskey. 1988. Deletion screening of Duchenne muscular dystrophy locus via multiplex DNA amplification. Nucleic Acids Res. 16: 1114111156.

6. Saad, F.A., L. Vitiello, L. Merlini, M.L. Mostacciuolo, S. Oliviero, and G.A. Danieli. 1992. A $3^{\prime}$ consensus splicing mutation in the human dystrophin gene detected by a screening for intra-exonic deletions. Hum. Mol. Genet. 1: 345-346.

7. Nigro, V., L. Politano, G. Nigro, S. Colonna Romano, A.M. Molinari, and G.A. Puca. 1992. Detection of nonsense mutation in the dystrophin gene by multiple SSCP. Hum. Mol. Genet. 1: 517-520.

8. Saad, F.A., G. Vita, M. Mora, L. Morandi, L. Vitiello, S. Oliviero and G.A. Danieli. 1993. A novel nonsense mutation in the 


\section{Technical TipsIIIIII}

human dystrophin gene. Hum. Mutat. (in press).

9. Hayashi, K. 1991. PCR-SSCP: A simple and sensitive method for detection of mutations in the genomic DNA. PCR Methods Applic. 1: 34-38.

Received March 30, 1993; accepted May 17, 1993. 


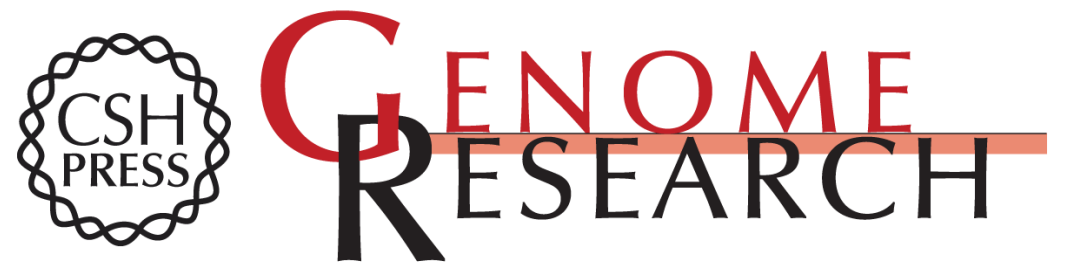

\section{Detection of unknown gene mutations by multiplex single-strand conformation polymorphism (MSSCP).}

F A Saad, L Vitiello, S Oliviero, et al.

Genome Res. 1993 3: 60-62

References This article cites 8 articles, 2 of which can be accessed free at: http://genome.cshlp.org/content/3/1/60.full.html\#ref-list-1

License

Email Alerting

Receive free email alerts when new articles cite this article - sign up in the box at the Service top right corner of the article or click here.

\section{Affordable, Accurate Sequencing.}

To subscribe to Genome Research go to: https://genome.cshlp.org/subscriptions 